Genome Insight

Genetics of Microorganisms

\title{
Genome sequence of Shewanella corallii strain A687 isolated from pufferfish (Sphoeroides spengleri)
}

Gustavo P. R. Azevedo ${ }^{1 *}$, Pedro H. C da Paz ${ }^{1 *}$, Hannah K. Mattsson ${ }^{1}$, Ana Paula B. Moreira ${ }^{1}$, Luciana Leomil $^{1}$, Gabriela Calegário ${ }^{1}$, Luciana Appolinario ${ }^{1}$, Lívia Vidal ${ }^{1}$, Bruno S. Silva ${ }^{1}$, Luciane A. Chimetto Tonon $^{2}$, Diogo A. Tschoeke ${ }^{1}$, Gizele D. Garcia ${ }^{1,3}$, Fabiano L. Thompson ${ }^{1}$ and Cristiane C. Thompson ${ }^{1}$ (iD)

${ }^{1}$ Universidade Federal do Rio de Janeiro, Institute of Biology and SAGE-COPPE, Rio de Janeiro, RJ, Brazil.

${ }^{2}$ Universidade de São Paulo, Instituto de Química de São Carlos (IQSC-USP), São Carlos, SP, Brazil. ${ }^{3}$ Universidade Federal do Rio de Janeiro, Departamento de Ensino de Graduação, Campus UFRJ-Macaé

Professor Aloisio Teixeira, Macaé, RJ, Brazil.

\begin{abstract}
We present here the genome sequence of Shewanella corallii strain A687 isolated from pufferfish Sphoeroides spengleri (Family Tetraodontidae). The assembly consists of 5,215,037 bp and contains 284 contigs, with a $\mathrm{G}+\mathrm{C}$ content of $50.3 \%$.

Keywords: Shewanella, gammaproteobacteria, genome, gene prediction, secondary metabolism.

Received: November 01, 2018; Accepted: March 12, 2019.
\end{abstract}

The genus Shewanella comprises 67 recognized species. These bacteria are Gram-negative, rod-shaped, facultatively anaerobic gammaproteobacteria and frequently isolated from marine environments (MacDonell and Colwell, 1985; Sugimoto et al., 2018). Shewanella species are involved in the production of antimicrobial metabolites and tetrodotoxin, a strong neurotoxin (Matsui et al., 1989; Simidu et al., 1990; Magarlamov et al., 2017). Shewanella corallii was recorded from red sea coral (Shnit-Orland, 2010). The aim of the present study was to determine the genome sequence of Shewanella corallii strain A687.

S. corallii A687 was isolated from pufferfish Sphoeroides spengleri (Family Tetraodontidae), in Arraial do Cabo (Brazil) in 2016. Genomic DNA was extracted according to Pitcher's protocol (Pitcher et al., 1989) and used for 300-bp paired-end library preparation with Nextera XT DNA Sample Preparation Kit. The genome was sequenced using MiSeq (Illumina, San Diego, CA, USA) as previously described (Walter et al., 2016). Sequences obtained were pre-processed using PRINSEQ software to remove reads smaller than $35 \mathrm{bp}$ and low-score sequences (Phred 30) (Schmieder and Edwards, 2011). Sequence reads were assembled using A5-Miseq (Coil et al., 2015) and CAP3

Send correspondence to Cristiane C. Thompson. Universidade Federal do Rio de Janeiro, Institute of Biology and SAGE-COPPE, Avenida Carlos Chagas Fo, s/n, Bloco A, Ilha do Fundão, CEP 21941-590, Rio de Janeiro, RJ, Brazil. E-mail: thompsoncristiane@gmail.com.

"These two authors contributed equally to this work. software (Huang and Madan, 1999). The gene prediction and functional annotation were performed using the RAST server (Overbeek et al., 2014). Secondary metabolism was analyzed by antiSMASH (Weber et al., 2015) and clustered regularly interspaced short palindromic repeat (CRISPR) arrays were determined with CRISPRFinder (Grissa et al., 2007).

The sequencing generated a total of $4,557,272$ reads and $768,079,097 \mathrm{bp}$ that were assembled in 284 contigs $(\mathrm{N} 50=298,540$ bp). The estimated genome size is $5,215,037$ bp with $\mathrm{G}+\mathrm{C}$ of $50.3 \%$, and a coverage of 146-fold. RAST predicted 4,555 coding sequences, and 175 RNA sequences (147 tRNAs, 11 16S rRNAs, $623 \mathrm{~S}$ rRNAs, and $115 \mathrm{~S}$ rRNAs). Analyzing the genes predicted by RAST, a total of 74 genes were involved in resistance to antibiotics and toxic compounds including copper homeostasis $(\mathrm{N}=8)$; bile hydrolysis $(\mathrm{N}=2)$; cobalt-zinc-cadmium resistance $(\mathrm{N}=20)$; resistance to fluoroquinolones $(\mathrm{N}=4)$; arsenic resistance $(\mathrm{N}=4)$; copper homeostasis: copper tolerance $(\mathrm{N}=6)$; tetracycline resistance, ribosome protection type II $(\mathrm{N}=2)$; beta-lactamase $(\mathrm{N}=5)$; multidrug resistance efflux pumps $(\mathrm{N}=22)$; resistance to chromium compounds $(\mathrm{N}=1) ; 24$ genes for the metabolism of aromatic compounds, including salicylate ester, chloroaromatic and quinate degradation. Phage elements sequences $(\mathrm{N}=44)$ were found in this genome, and CRISPRs arrays candidates were predicted in four sequences. We searched through subsystems for genes associated to symbiosis. Genes encoding type I, (lapBCDE, lapL, lapP, RTX and TolC) and type II 
(TadA, TadB, TadC, VirB11, RcpC, CpaB and CpaF) secretion systems were detected. We also identified 16 genes related to vitamin B12 synthesis and four LuxR gene families (Bondarev et al., 2013).

\section{Data availability}

This whole-genome shotgun project has been deposited in GenBank under the accession number QRCS00000000. The version described in this paper is the first version.

\section{Acknowledgments}

The authors thank CNPq, CAPES (Brasil - Finance code 001), and FAPERJ for their financial support. This paper is part of the D.Sc. requirements of Gustavo Pitta Reis de Azevedo (Genetics Graduate Program at the Federal University of Rio de Janeiro). LACT thanks FAPESP.

\section{Conflict of Interest}

The authors declare no conflicts of interests related to this work.

\section{Author Contributions}

GPRA and PHCP carried out the genomic and computational analysis, analyzed the results and wrote the manuscript. HKM, APBM, LV, BSS and LACT, GDG helped analyze the results, participated in the discussion and in the draft of the manuscript. LL, GC and LA carried out the genome sequencing and helped analyzing the results. DAT helped with genomic and computational analysis and drafted the manuscript. CCT and FLT conceived the study, analysed the data and wrote the manuscript. All authors read and approved the final manuscript.

\section{References}

Bondarev V, Richter M, Romano S, Piel J, Schwedt A and Schulz-Vogt HN (2013) The genus Pseudovibrio contains metabolically versatile bacteria adapted for symbiosis. Environ Microbiol 15:2095-2113.

Coil D, Jospin G and Darling AE (2015) A5-miseq: An updated pipeline to assemble microbial genomes from Illumina MiSeq data. Bioinformatics 31:587-589.

Grissa I, Vergnaud G and Pourcel C (2007) CRISPRFinder: A Web tool to identify clustered regularly interspaced short palindromic repeats. Nucleic Acids Res 35:W52-W57.
Huang X and Madan A (1999) CAP3: A DNA sequence assembly program. Genome Res 9:868-877.

MacDonell MT and Colwell RR (1985) Phylogeny of the Vibrionaceae, and recommendation for two new genera, Listonella and Shewanella. Syst Appl Microbiol 6:171-182.

Magarlamov TY, Melnikova DI and Chernyshev AV (2017) Tetrodotoxin-producing bacteria: Detection, distribution and migration of the toxin in aquatic systems. Toxins (Basel) 9:166.

Matsui T, Taketsugu S, Kodama K, Shiba-Ishii A, Yamamori K, Shimizu C and Shira-Ishi A (1989) Production of tetrodotoxin by the intestinal bacteria of a puffer fish Takifugu niphobles. Nippon Suisan Gakkaishi 55:2199-2203.

Overbeek R, Olson R, Pusch GD, Olsen GJ, Davis JJ, Disz T, Edwards RA, Gerdes S, Parrello B, Shukla M et al. (2014) The SEED and the Rapid Annotation of microbial genomes using Subsystems Technology (RAST). Nucleic Acids Res 42:D206-D214.

Pitcher DG, Saunders NA and Owen RJ (1989) Rapid extraction of bacterial genomic DNA with guanidium thiocyanate. Lett Appl Microbiol 8:151-156.

Schmieder R and Edwards R (2011) Quality control and preprocessing of metagenomic datasets. Bioinformatics 27:863-864.

Shnit-Orland M, Sivan A and Kushmaro A (2010) Shewanella corallii sp. nov., a marine bacterium isolated from a Red Sea coral. Int J Syst Evol Microbiol 60:2293-2297.

Simidu U, Kita-Tsukamoto K, Yasumoto T and Yotsu M (1990) Taxonomy of four marine bacterial strains that produce tetrodotoxin. Int J Syst Evol Microbiol 40:331-336.

Sugimoto Y, Maruyama F and Suzuki S (2018) Draft genome sequence of a Shewanella halifaxensis strain isolated from the intestine of marine Red Seabream (Pagrus major), which includes an integrative conjugative element with macrolide resistance genes. Genome Announc 6:e00297-18.

Walter JM, Tschoeke DA, Meirelles PM, de Oliveira L, Leomil L, Tenório M, Valle R, Salomon PS, Thompson CC and Thompson FL (2016) Taxonomic and functional metagenomic signature of turfs in the Abrolhos reef system (Brazil). PLoS One 11:e0161168.

Weber T, Blin K, Duddela S, Krug D, Kim HU, Bruccoleri R, Lee SY, Fischbach MA, Müller R, Wohlleben W et al. (2015) AntiSMASH 3.0 - a comprehensive resource for the genome mining of biosynthetic gene clusters. Nucleic Acids Res 43:W237-W243.

\section{Associate Editor: Ana Tereza R. Vasconcelos}

License information: This is an open-access article distributed under the terms of the Creative Commons Attribution License (type CC-BY), which permits unrestricted use, distribution and reproduction in any medium, provided the original article is properly cited. 